\title{
VISEGRAD EUROSCEPTICISM: DISCURSIVE NODAL POINTS IN EUROSCEPTIC DISCOURSES SURROUNDING EXTERNAL ACTIONS OF THE EUROPEAN UNION
}

\author{
Asst. prof. dr. Filip Tereszkiewicz \\ Chair of Intellectual Property, Administrative and European Law, part of the Faculty \\ of Economy and Management, Opole University of Technology. \\ f.tereszkiewicz@gmail.com
}

\section{DOI:10.24193/OJMNE.2018.26.10}

\begin{abstract}
Increasing support for Eurosceptic parties and movements can be observed in the European Union's (EU) member states since 2009, when the economic crisis heavily affected the continent. This process has happened also within Central and Eastern European countries, especially in Poland, the Czech Republic, Slovakia and Hungary (collectively referred to as the Visegrad Group countries, or V4 for short). The goal of this paper is an analysis of far-right Eurosceptic politicians and their attitudes towards EU external actions. Using the Thomas Diez concept of discursive nodal points (DNPs) and examining European Parliament (EP) debates, literature about V4 Euroscepticism and media reports, this paper attempts to give answers about their attitudes to aspects of EU external actions. First, the notion of Euroscepticism is examined and the main difficulties with the definition are briefly discussed. Then, the methodology of this research and the concept of DNPs are laid out. The following section pays attention to V4 Eurosceptic politicians' (V4E) attitudes towards five areas of EU external actions: EU-Russia relations, EU defence policy, environmental policy, development assistance policy, and the Transatlantic Trade and Investment Partnership (TTIP) issue. In the conclusion, the author summarises that V4 Eurosceptics are divided in their positions towards EU external actions. Paradoxically, they are linked not in the being in opposition towards the EU, but rather in having pro-Russian attitudes and being against any EU activity that would violate Kremlin's interests.
\end{abstract}

Keywords: Constructivism, Euroscepticism, EU`s external action, Visegrad, far-right

\section{Introduction}

The increase in popularity of Eurosceptic parties and movements among EU member states has been a subject of debates among scholars and journalist for many years, especially since the global economic crisis that seriously affected Europe in 2009. One of the most 
important observations is that negative attitudes towards the EU is a part of the "populism ideology," meaning that in the EU a marriage between Euroscepticism and populism can be observed (Eiermann et al., 2017). In the context of populism, Martin Eiermann et al. make the latter observation, arguing that the so-called Old Continent has been divided into four parts: Eastern, Western, Southern and Northern Europe. As the authors state, Eastern Europe has featured an unprecedented increase in societal support for populistic and Eurosceptic parties since 2000. While they gained an average of $9.2 \%$ of the national vote in 2000 , their vote share reached 31.6\% in 2017 (2017). Among the Eastern Europe group are the Visegrad Group (V4) countries: Poland, the Czech Republic, Slovakia and Hungary. Thus, this observation is also true for these countries. Moreover, this increasing societal support for such parties has pushed mainstream parties towards more populistic and Eurosceptic positions, as V4 governments are led by the parties that represent negative attitudes towards the EU, although they are not stringently Eurosceptic (Fidesz in Hungary, Smer in Slovakia, Ano in Czechia, and PiS in Poland).

Instead of dwelling on this shift, this paper is focused on V4 governing party competitors that represent the more visible anti-EU attitude, as well as rival mainstream parties from the far-right. In the researched literature, they are referred to by Christopher Lord as the untidy right (1998). The focus of this paper is an analysis of far-right V4Es and their attitudes towards EU external action, and poses several questions: Do these parties take part in discussions about EU foreign policy? How are their attitudes towards these areas: negative or critical (or even positive, as it can be observed to some extent among Western European Eurosceptics (Tereszkiewicz, 2016b))? Are they divergent or similar in their position towards EU external actions? Answers to these questions are important for two reasons. First, as Aleks Szczerbiak and Paul Taggart mention, knowledge about Eurosceptic parties and movement is still facile and needs wider and deeper research (2018). Second, the aforementioned V4 mainstream parties move on the political axis towards far-right competitors, and therefore could take some elements of the untidy right attitudes about EU external actions, which may have an impact on EU foreign policy.

Using the Thomas Diez concept of discursive nodal points (DNPs) and examining European Parliament (EP) debates, literature about V4 Euroscepticism, and media reports, this paper attempts to answer the above questions. The study is based on the hypothesis that 
V4Es are divided in their attitudes towards EU external actions, ranging from total opposition to critical acceptance.

The article proceeds as follows: first, the notion of Euroscepticism is examined and the main difficulties with the definition are briefly discussed. Then, the methodology of this research and the concept of DNPs are laid out. The following section pays attention to V4Es attitudes towards five areas of EU external actions: EU-Russia relations, EU defence policy, environmental policy, development assistance policy, and the Transatlantic Trade and Investment Partnership (TTIP) issue. The conclusion summarises the main findings and reflects on the inquiry about V4Es attitudes towards EU external actions, with questions resulting from the analysis providing a perspective for further research.

\section{Euroscepticism: difficulties with defining}

Even though there have been many publications about Euroscepticism, there is a dispute between scholars over what exactly this notion means, and about the scope of opinion that is within its framework (Szczerbiak and Taggart, 2018). The concept of Euroscepticism was named into existence by some scholars, but they did so within areas of their research interest; only a few of them have tried to create a definition that covers the whole spectrum of Euroscepticism (Leruth et al., 2018). Until now, there has been no commonly accepted definition of the term (Vasilopoulou, 2018). Differences between definitions focus on the scale of the opposition against European integration, and also on the future of cooperation within the European Union (Vasilopoulou, 2011). Furthermore, along with the increase in Eurosceptic attitudes within European societies, and the more common presence of Eurosceptic politicians within EU institutions, the scope of their attention must be broader. These developments create a situation in which it is even harder to define Euroscepticism and the ideas it contains (Leruth et al., 2018).

Circumstances in which the term "Euroscepticism" has come up are also a source of problems with defining this notion. The term was created by British journalists who use academic jargon in their journalistic writing (Spiering, 2004). C. Flood and R. Soborski note that the usage of the suffix "-ism” creates a situation wherein many people think that Euroscepticism has some ideological content, which is not true (2018). Even though the first book about Euroscepticism was published in 1997 (Benoit, 1997), and the first 
conceptualisation of it was done in 1998 by Paul Taggart (2003), it is still difficult to say that Euroscepticism as a concrete idea exists. However, the definition of Euroscepticism prepared by Krzysztof Zuba, who says that Euroscepticism is a political attitude that contests the integration process within any part of Europe (2006), is chosen for the foundation of this paper. This definition has weaknesses that are common to other definitions of the term because it emphasises its negative and blurry character. It does not speculate as to why this negative attitude exists, offer any alternatives to integration, or speculate what end it leads to, creating confusion over what exactly links Eurosceptic movements and groups, aside from a negative attitude towards the EU (Leruth et al., 2018). Aleks Szczerbiak and Paul Taggart confirm this problem, remarking that there is little research that analysis on the influence of Euroscepticism on EU politics (2018). For that reason, the main goal of this paper is to fill in the research gap in the area of the Visegrad Eurosceptics' influence on EU external actions.

\section{Methodology: Discourse and discursive nodal points}

The aforementioned amorphism of Euroscepticism is a problem for scholars. For many years, they have tried to find analytical tools and approaches that are useful in researching Eurosceptic parties and movements. In spite of these efforts, most publications concentrate on comparative analyses of political parties in EU member states (Vasilopoulou, 2018). Considering these methodological problems, this paper uses the potential of the constructivist approach to research far-right Eurosceptic attitudes towards EU external actions. This approach has many useful tools that help develop knowledge of Euroscepticism (Tereszkiewicz, 2016a). One of them is discourse analysis, which is used in this paper to catch discursive nodal points (DNP).

One of the definitions of the term discourse was created by Thomas Diez, who states that the discourse is a set of opinions about a particular subject created during a discursive process. He also notes that there is not one detached discourse about a particular thing or topic because there are simultaneous diversified discursive streams (1998). In conducting the study of the discourse about EU external actions, we can abstract the Eurosceptic discourse. It is possible to define many streams, one of which is the Eurosceptic discourse among politicians from countries that are members of the Visegrad Group (also known as the 
Visegrad Four, or V4). The main goal of this paper is to study this discourse, and to identify within it DNPs.

T. Diez also states that knowledge about a topic presented by discourse participants does not present an objective substance, but creates a subjective picture of this substance. Therefore, this picture is not always consistent with facts, and various discursive constructions are possible (1996). Therefore, the V4 Eurosceptic discourse about EU external actions is not necessary consistent with facts. However, it shows how these Eurosceptic politicians perceive and conceive the EU's role on the global scene. Therefore, the analysis of V4E discourse surrounding EU foreign policy can help to capture their view about a place that, in their opinion, is predicted for the Union in the international arena. It also helps to research whether or not they allow the EU to be active in the global scene, and this enables the verification of the hypothesis that is established by the author.

The main goal for DNPs is to capture the common meaning shaped within the analysed discourse. According to this concept, streams that exist within one discourse are interweaving and thereby create new discourses in nodal points. Diez also states that the analysis of DNPs allows a construction from various discursive streams of a dominant discourse within a particular group or community (1998). Therefore, the reconstruction of DNPs found in V4E discourse allows us to develop our knowledge about Euroscepticism.

To construct this discourse, European Parliament debates and related literature about V4 Euroscepticism were analysed, including media such as websites and newspapers. Screening of the social media pages of politicians and political parties from this region was also conducted.

This paper is focused on political parties located on the far right of the spectrum. In the researched literature, they are named the untidy right (Lord, 1998, Brack, 2012) - their common feature is being in the opposition towards the EU and the integrating process within the continent mainly for political and cultural reasons. They stand in the contrast to far-left Eurosceptic parties that are against the EU mainly for economic reasons (Brack, 2012). We can count among the untidy right the following parties from V4 countries:

Jobbik Magyarországért Mozgalom, Jobbik (The Movement for a Better Hungary) from Hungary; 
Issue no. 26/2018

Wolność (Liberty), Kongres Nowej Prawicy, KNP (The Congress of the New Right), and Ruch Narodowy, RN (National Movement) from Poland;

Strana svobodných občanů, SSO (Party of Free Citizens) and Svoboda a př́má demokracie, SPD (Freedom and Direct Democracy) from Czechia; and

Slovenská národná strana, SNS (The Slovak National Party) and Kotleba Ludová strana Naše Slovensko, L'SNS (The People's Party - Our Slovakia) from Slovakia.

\section{Relations with Russia}

Firstly, it is important to note that almost all untidy right parties are linked with Russia (ABE, 2018). They get financial or political support from the Kremlin and oligarchs linked to Vladimir Putin. Moreover, some of the V4Es, like Béla Kovács from Jobbik, Janusz Korwin-Mikke from Wolność, and Sylwester Chruszcz from RN, are accused of being Russian operatives (Krekó et al., 2016, Beswick, 2017). Therefore, members of these parties also present friendly attitudes towards Russia. In Russian-friendly Eurosceptic discourse, we can identify three streams regarding the neighbour to the east.

The first is the narrative that Russia only defends its interests in Ukraine and Syria, therefore Europe must understand its activity in these areas and take a neutral position. For example, Zlatan Balczó (Jobbik), Janusz Korwin-Mikke (Wolność) and Tomio Okamura (SPD) posit that Russia only defends itself from the supposed aggression stemming from American involvement in the Maidan revolution, as well as NATO's advances on Kiev (Balczó, 2015e, Balczó, 2015a, Balczó 2015, Balczó, 2014b, Korwin-Mikke, 2014, SPD, 2018). V4Es insist that Crimea belongs to Russia because in the past this peninsula was a part of the tsarist empire. Moreover, they uphold that people decided via a 2014 referendum that they want to be within the Russian state (Tesařová, 2017, 2017e), thus justifying the stance of their ally.

In the second stream, V4Es underline the ineffectiveness of sanctions that are used by the EU against Russia after the Crimea invasion; they state that the Russian economy is in good condition, by contrast to the EU and its member states (Fiala, 2017). According to V4Es, negative economic sanctions emasculate EU member-states' economies (Balczó, 2017b, Balczó, 2015e, Chruszcz and Dziambor, 2014, Švec, 2017, FTV, 2014, Mazurek, 
Issue no. 26/2018

2015, 2017b). Sometimes they highlight negative influence of sanctions for particular sectors (e.g. the Jobbik politicians' focus on farming (Balczó, 2017b), and SPD on tourism (FTV, 2014)).

The third stream is about economic links between Europe and Russia. V4Es stress that Europe must cooperate with Russia. According to them, instead of being in conflict, the two sides should trade with each other (Chruszcz and Dziambor, 2014, Fiala, 2017). They also state that Europe needs Russian fossil fuels (TASR, 2017) and, furthermore, insist that Europe needs the Kremlin to resolve crucial problems in the neighbourhood. They say it is impossible to win a war against terrorism (especially with Islamic state (Fiala, 2017)) and to stabilise the Middle East without cooperating with Russia (2017b, Hutko, 2017, SPD, 2018, Balczó, 2015e).

With these three discursive streams, we can construct a DNP. All V4Es emphasise that Europe and Russia are closely related to each other, stating that mutual problems should be resolved by using diplomatic negotiations instead of negative measures (TASR, 2017, Balczó, 2015e). For these reasons, V4Es call on the EU and its member states to reset its policy towards Moscow as Donald Trump did (Balczó, 2017b). If some countries perceive the Kremlin as a threat, politicians from these countries should work to change that opinion (Tesařová, 2017). Andrej Danko (SNS) also notes that the V4 and Russia have many things in common because of Slavic roots (except, of course, Hungary) (2017c).

\section{The European Union defence policy}

The EU defence policy issue, collaterally to the relationship with Russia, is an area where V4Es have a similar point of view. Primarily, they are against any EU-related cooperation in this field. Four reasons, or discursive streams, can be distinguished as to why they have such negative attitudes towards EU defence policy. First, which is common among Eurosceptics, is the fear that the Common Security and Defence Policy (CSDP), the Permanent Structured Cooperation (PESCO) and any other cooperation in this area mark a step towards a European federal state. A crucial part of the Eurosceptic movement and party persuasion is directed against deeper integration within a potential European state, therefore they are against closer cooperation in the defence field (Balczó, 2017c, Gergely, 2016, Mach, 2015a, Mach, 2016e, SPD, 2017a, Korwin-Mikke, 2016b, Korwin-Mikke, 2017a, Marusik, 
2017). The second reason has roots in their understanding of why the EU would need PESCO or a European army. Some parties like Wolność and SPD are convinced that the European army would be used to suppress member states if Eurosceptic politicians won the electoral competition and moved for their home countries to secede from the EU (SPD, 2017c, Korwin-Mikke, 2017c). The third, often used to explain resistance to increasing cooperation in EU defence matters, is concerned with lobbying. Some Eurosceptic politicians are convinced that PESCO was established because the military-industrial complex has persuaded the Commission that they need a new source of money (Kovács, 2016b, Kovács, 2015b). Others see PESCO as a good opportunity to take money by corrupt EU officials (Korwin-Mikke, 2015b, Korwin-Mikke, 2017b, Korwin-Mikke, 2016a). The final stream focuses on immigration, especially illegal immigration and any related Islamic terrorism, which, according to them, is now the most important threat to Europe. These politicians state that the EU has shown its incapability to resolve the last migration crisis, thereby it has no right to develop its own military capacity (Kovács, 2016b, Mach, 2016d, Okamura, 2017, Winnicki, 2017).

Two DNPs can be identified within these discursive streams. Some V4Es believe that the EU is weak and has no potential to effectively develop military cooperation between its member states. According to some politicians from Jobbik and Wolność, Brussels could be easily abused by the military-industrial complex and corrupt politicians to earn extra money. Other politicians state that the last immigration crisis shows that the EU is ineffectual in the use of its power, and the last thing it needs is more (Jobbik, SSO, SN, LSNS). The second DNP presents a different interpretation of this policy, wherein the EU is powerful and needs its own army to build a federal state and preserve its own interests, especially within member states (SPD, Wolność, KNP).

\section{The environmental policy}

The discourse about environmental policy shows that V4Es are divided into two groups. In the first one, there are politicians who support this area of EU activity. This opinion is common among members of Jobbik, SPD and SNS, whom we will call the "pro" group. They agree that climate change is a real global problem and that it should be resolved on the international stage (Balczó, 2014a, Okamura, 2014). In their opinion, the Paris 
agreement that was made within the United Nations Framework Convention on Climate Change, $21^{\text {st }}$ Conference of the Parties (COP 21) is a good step towards international activity that helps limit greenhouse gases emission (Balczó, 2015c). Nevertheless, they think that all measures that will be conducted within the Paris agreement framework make no sense if the US and China, which are the two main greenhouse gas emitters on Earth, do not take part (Balczó, 2015f, Balczó, 2015d, 2017a, Balczó, 2017a).

Politicians who think that climate change is a fabrication of scientists, politicians and businessmen comprise the second, or "anti” group, which includes activists from Wolność, KNP RN, SSO and LSNS. Polish Eurosceptics argue that these changes are not the result of human activity, which differentiates them from others V4Es (Marusik, 2016, Marusik, 2015, Iwaszkiewicz, 2017). According to members of these parties, the EU environmental policy is detrimental to the European economy and, more importantly, to its citizens. This policy brings higher energy costs as well as increases in taxes and prices of food, limits economic growth and discourages business in Europe (Mach, 2016b, Mach, 2016c, Iwaszkiewicz, 2017, Winnicki, 2016, RN, 2016b, 2013). Therefore, this policy increases poverty in Europe and in the rest of the world (Marusik, 2016, Marusik, 2015). EU environmental policy, by Polish Eurosceptic accounts, was devised by the "green industry," corrupt politicians, and scientists to make money (Iwaszkiewicz, 2017). This side also took part in discussions about the Paris agreement. In their opinion, this international accord is an effect of the lobbying conducted by corrupted politicians (Marusik, 2016, Marusik, 2015). However, Petr Mach (SSO) argued in his statement that the Paris agreement will be completely ineffective because this accord does not institute any sanctions for breaking its provisions (Mach, 2016c).

Only one DNP can be reconstructed into this discourse. Regardless of the opinion about climate change, all V4Es agree that EU policy in this area is ineffective and therefore needs revision. They also have a common opinion that this ineffectiveness brings higher costs for the European economy and societies. However, they are divided on what the EU should do. According to the pro group, the US and China must be involved in global activity in this area. In contrast, the anti group think that EU member states must, as fast as possible, move out of this policy. They also diverge in the assessment of which sources of energy should be developed. According to Jobbik, the atomic industry brings energy safety (Balczó, 2014a, Balczó, 2015f). Members of SPD assert that the future belongs to renewable energy sources 
that should be mixed with fossil fuels (Okamura, 2014). In contrast, Polish Eurosceptics (Wolność, KNP and RN) focus on the coal industry as the main source of energy (2013), while members of SNS and LSNS maintain that the gas industry is good for the Slovak economy (2017a).

\section{The development assistance policy}

V4Es are also divided on the matter of the development assistance policy. The first group, similarly to the pro-environmental group in composition, are members of Jobbik, SPD and SNS, who generally think that this policy is necessary and useful (Kovács, 2015a). In their opinion, the main advantage of this policy is helping limit migration to Europe. If the EU and its member states help underdeveloped countries improve their economic situation, people would stay there. Therefore, according to this group of Eurosceptics, it is better to help abroad, especially in Africa, than have migrants at home (Balczó, 2016, Kovács, 2016c, 2017d, vef, 2017).

The second group, similar to the antis, stay on the position that development assistance policy is a waste of money. Within this group, two discursive streams can be distinguished. Some of these politicians criticise this policy from the liberal position, e.g. members of SSO think that Europe should develop economic relations with these countries rather that give them development assistance (Mach, 2016f, Mach, 2016g). According to them, Africa, Caribbean and Pacific countries (ACP) could compete with the EU if they employed a tax policy (Mach, 2016a). On this same side are members of Wolność and KNP, because they are against any state activity that need taxpayer money. The second group also criticises this policy, however, on social grounds. According to members of RN and LSNS, European governments should primarily give financial assistance to poor people at home rather than help people abroad.

V4Es are also divided in opinion over the development assistance policy, which was shown by the conducted analysis. A spectrum of opinion ranges from acceptance (because it stops migration to Europe and also helps bolster the international position of member states (Jobbik, SPD, SNS) (Kovács, 2016c, SPD, 2017b) to resistance (because it is seen as promoting European values like gay rights, gender issues, and political correctness (Wolność, KNP, RN, SSO and LSNS)). Regardless of that, we can identify a DNP within V4E discourse 
about the development assistance policy. All politicians agree that this policy is ineffective, and within such a framework a lot of money is wasted (vef, 2017, SPD, 2017b, Mach, 2016f, Kovács, 2016a). However, they are divided over the recipe for this policy. One group argues that the rules that shape this policy should be changed to show transparency. Other politicians state that this policy, to save taxpayer money or increase social policy in their own countries, should be limited or abolished.

\section{Transatlantic Trade and Investment Partnership}

V4Es are also divided on the issue of TTIP. However, in the aforementioned cases of the environmental and the development assistance policy, pro and anti groups have exactly these same members. In contrast, the TTIP issue creates a completely different division. Members of two parties (SSO and Wolność) support to some extent this EU-US agreement. The main reason for their support has ideological roots; they support economic freedom and international trade, so they agree with the concept of free trade with the USA (Mach, 2015b, Iwaszkiewicz, 2015, Korwin-Mikke, 2015a). Nevertheless, members of these parties have some reservations about TTIP. For them, this agreement will not create free trade between Europe and America, but will instead bring new restrictions (Mach, 2014, Korwin-Mikke, 2015a). They point to non-transparency in the negotiation process, voicing special objection to the arbitration mechanism (the investor-state dispute settlement, or ISDS). In their opinion, it puts member states' governments in a weak position during confrontations with international companies. Politicians form SSO and Wolność also state that European food standards could be undermined in competition with industrial and, thereby, cheaper US products (Mach, 2015b, Iwaszkiewicz, 2015, Korwin-Mikke, 2015a).

The rest of the V4Es (Jobbik, RN, SPD, SNS and LSNS) are against TTIP. In the discussion about the partnership with the USA, they use similar arguments, saying that the agreement is unfavourable for the European economy and profits only international companies (Balczó, 2014c, Balczó, 2015b, Okamura, 2016, Hrnčíř, 2016, ste, 2016a) (ste, 2016b). Moreover, they predict food security standards will be weakened in Europe because GMO products are legal in the US, and the American meat industry can use hormones during the breeding process (Okamura, 2016, Balczó, 2015b, RN, 2016a). They are opposed to TTIP because it will establish ISDS; in this manner, they are similar to politicians from SSO and 
Wolność. V4Es emphasise that the arbitration mechanism could preclude the implementing of changes in economic policy when Eurosceptic parties take power in their respective countries. International investors could use ISDS if future governments make decisions that limit its gains (Balczó, 2014c, Okamura, 2016, Hrnčíŕ, 2016, Bosak, 2016).

In TTIP discourse, two common DNPs can be isolated. The first is anxiety about food standards that are higher in Europe compared to the US, where fears exist that the new agreement with the USA could decline the food security in their home countries (sometimes they use exactly these same reasons, e.g. introducing GMOs into the food supply). The second is the objection to the ISDS mechanism that could limit the potential of future Eurosceptic governments in member states.

\section{Conclusions}

The above analysis shows that Eurosceptic politicians from Visegrad Group countries are divided on their opinions about the EU's external actions. This divergence concerns two things: the salience of topics and participation in discussions and attitudes towards particular areas of EU foreign policy. The author's research shows two variables that increase the V4Es' presence in discussions about EU external actions, the first being representation in the European Parliament. Jobbik, Wolność and KNP all currently have seats in Brussels. Parliament members (also known as MEPs) frequently take part in debates about areas of EU policy because they must show their supporters that they fight actively and consistently for their interests. Eurosceptics are gathered into small factions (Europe of Freedom and Direct Democracy, and Europe of Nations and Freedom Group) which are represented in debates, or are independent and have limited options to be visible. The second variable refers to individual interests of members of these parties, especially their leaders. If a V4E is focused on a certain issue, he frequently makes comments on it, as observed by Zoltán Balczó's (Jobbik) and Michał Putkiewicz's (SN) attitudes toward EU environmental policy, and Janusz Korwin-Mikke’s remarks about CSDP.

If we try generally assessing V4E attitudes towards EU foreign policy, it is apparent that they are divided in their opinions on it. Some of them have a negative stance toward all issues (KNP, RN and L'SNS), and others (Wolność and SSO) have negative attitudes towards EU activity on the international stage while tolerating some activities such as 
external trade policy (most notably TTIP). Others still have critical attitudes towards EU external actions, albeit not totally negative. Members of Jobbik, SPD and SNS support, to some extent, the role that is played by the Union in environmental and development assistance policies. Their objections are concerned with the ineffectiveness of EU institutions, and therefore they call for some changes in these EU policies.

V4Es have a similar stance on two issues: EU-Russia relations and the EU defence policy, to which they are opposed. Only one DNP can be distinguished in the discourse about Russia, largely dealing with mutual problems between Europe and Russia, and the need to solve them by using diplomatic negotiations instead of negative measures. Two DNPs are found in the EU defence policy issue, the first being that the EU is weak and has no potential to effectively develop military cooperation between its member states, and the second being that the EU is powerful and needs its own army to build a federal state and preserve its own interests. These DNPs indicate that V4Es are divided in their perceptions of the EU's potential in the defence area, although they are united against any EU activeness in this area.

DNPs can be identified within discourses about EU foreign policy as well, especially with regard to environmental and development assistance policies. There are, once again, two groups: one (Jobbik, SPD and SNS) has positive attitudes towards these policies (though they have objections about the effectiveness of these policies), while the second (Wolność, KNP, RN, L'SNS and SSO) has a wholly negative perception of these policies. Despite this split, one DNP about that EU policy in these areas being ineffective can be identified, which shows that some discursive coherence does exist among V4Es. This same situation can be observed within discourses about TTIP, although the groups consist of different members (Wolność and SSO are pro, the rest are anti). Two DNPs can be pinpointed in the TTIP issue: anxiety about food standards and the objection to the ISDS mechanism, though these also show coherence between V4Es rather than division.

This paper shows that V4Es are divided on their position towards EU external actions. Therefore, the working hypotheses are confirmed, which show that, to some extent, V4 Euroscepticism is similar to its Western European version. The division over the EU's external role can be observed in Euroscepticism in all EU member states, which shows that it is not a coherent political movement. Paradoxically, V4Es - and likely other Eurosceptics are linked not in being in opposition towards the EU, but rather in having pro-Russian 
attitudes and being against any activity that would go against the Kremlin's interests, such as sanctions against Russia and EU defence policy. Therefore, further research should be conducted in two areas: where Eurosceptic politicians see foreign policy competencies for the EU, and possible connections between Russia and Eurosceptic parties and movements.

\section{References}

- 2013. Anty-Szczyt przeciwko zaostrzaniu polityki klimatycznej [Online]. TVP3. Available: $\quad$ http://tvp3.tvp.pl/12974590/antyszczyt-przeciwko-zaostrzaniu-politykiklimatycznej [Accessed 13.04.2018 2018].

- 2017a. Danka zarazilo rozhodnutie prezidenta Trumpa odstúpit’od parížskej dochody [Online]. WebNoviny. Available: https://www.webnoviny.sk/danka-zarazilo-rozhodnutieprezidenta-trumpa-odstupit-od-parizskej-dohody/ [Accessed 12.04.2018 2018].

- $\quad$ 2017b. Danko chce prejav v Rusku vysvetlit', $k$ anexii Krymu uviedol, že nie je historik [Online]. SME Domov. Available: https://domov.sme.sk/c/20702741/danko-prejav-v-ruskuvysvetlim-sokuje-ma-spolupraca-sas-s-lsns.html\#ixzz5CRu3OgPX [Accessed 29.03.2018 2018].

- $\quad$ 2017c. Danko vystúpil s prejavom v ruskej Štátnej dume, vyzdvihol najmä slovanskú históriu oboch krajín [Online]. WebNoviny. Available: https://www.webnoviny.sk/dankovystupil-s-prejavom-v-ruskej-statnej-dume-vyzdvihol-najma-slovansku-historiu-obochkrajin/ [Accessed 30.03.2018 2018].

- $\quad$ 2017d. Je třeba pomáhat v místě původu. Proto omezíme rozvojovou pomoc, zní z SPD [Online]. Available: http://denikreferendum.cz/clanek/26701-je-treba-pomahat-v-mistepuvodu-proto-omezime-rozvojovou-pomoc-zni-z-spd [Accessed 18.04.2018 2018].

- $\quad$ 2017e. Slovenská opozice navrhla uznat Krym za součást Ruska [Online]. Sputnik. Available: $\quad$ https://cz.sputniknews.com/slovensko/201711246322074-Slovenska-opoziceKrym-soucast-Rusko/ [Accessed 27.03.2018 2018].

- $\quad$ BALCZÓ, Z. 2014a. 2014 UN Climate Change Conference - COP 20 in Lima, Peru (1-12 December 2014) [Online]. European Parliament. Available: http://www.europarl.europa.eu/sides/getDoc.do?pubRef=- 
//EP//TEXT+CRE+20141126+ITEM-007+DOC+XML+V0//EN [Accessed 10.04.2018 2018].

- $\quad$ BALCZÓ, Z. 2014b. Situation in Ukraine and state of play of EU-Russia relations (debate) [Online]. European Parliament. Available: http://www.europarl.europa.eu/sides/getDoc.do?pubRef=//EP//TEXT+CRE+20140916+ITEM-004+DOC+XML+V0//EN [Accessed 27.03.2018 2018].

- BALCZÓ, Z. 2014c. Transatlantic Trade and Investment Partnership (TTIP) [Online]. European Parliament. Available: http://www.europarl.europa.eu/sides/getDoc.do?pubRef=//EP//TEXT+CRE+20140715+ITEM-009+DOC+XML+V0//EN [Accessed 23.04.2018 2018].

- $\quad$ BALCZÓ, Z. 2015a. Annual report from the High Representative of the European Union for Foreign Affairs and Security Policy to the European Parliament (debate) [Online]. European Parliament. Available: http://www.europarl.europa.eu/sides/getDoc.do?pubRef=//EP//TEXT+CRE+20150311+ITEM-014+DOC+XML+V0//EN [Accessed 27.03.2018 2018].

- BALCZÓ, Z. 2015b. Negotiations for the Transatlantic Trade and Investment Partnership (TTIP) [Online]. European Parliament. Available: http://www.europarl.europa.eu/sides/getDoc.do?pubRef=//EP//TEXT+CRE+20150707+ITEM-004+DOC+XML+V0//EN [Accessed 23.04.2018 2018].

- BALCZÓ, Z. 2015c. Outcome of the COP 21 [Online]. European Parliament. Available: $\quad$ http://www.europarl.europa.eu/sides/getDoc.do?pubRef=//EP//TEXT+CRE+20151215+ITEM-009+DOC+XML+V0//EN [Accessed 12.04.2018 2018].

- $\quad$ BALCZÓ, Z. 2015d. Roadmap towards a new international climate agreement in Paris [Online]. European Parliament. Available: http://www.europarl.europa.eu/sides/getDoc.do?pubRef=- 
//EP//TEXT+CRE+20150128+ITEM-014+DOC+XML+V0//EN [Accessed 12.04.2018 2018].

- $\quad$ BALCZÓ, Z. 2015. Situation in Ukraine (debate) [Online]. European Parliament. Available: http://www.europarl.europa.eu/sides/getDoc.do?pubRef=//EP//TEXT+CRE+20151014+ITEM-018+DOC+XML+V0//EN [Accessed 27.03.2018 2018].

- $\quad$ BALCZÓ, Z. 2015e. State of EU-Russia relations (A8-0162/2015 - Gabrielius Landsbergis) [Online]. European Parliament. Available: http://www.europarl.europa.eu/sides/getDoc.do?pubRef=//EP//TEXT+CRE+20150610+ITEM-009-05+DOC+XML+V0//EN [Accessed 27.03.2018 2018].

- $\quad$ BALCZÓ, Z. 2015f. Towards a new international climate agreement in Paris [Online]. European Parliament. Available: http://www.europarl.europa.eu/sides/getDoc.do?pubRef=//EP//TEXT+CRE+20151014+ITEM-014+DOC+XML+V0//EN [Accessed 12.04.2018 2018].

- $\quad$ BALCZÓ, Z. 2016. The future of ACP-EU relations beyond 2020 [Online]. European Parliament. Available: $\quad$ http://www.europarl.europa.eu/sides/getDoc.do?pubRef=//EP//TEXT+CRE+20161004+ITEM-008-09+DOC+XML+V0//EN [Accessed 17.04.2018 2018].

- $\quad$ BALCZÓ, Z. 2017a. 2017 UN Climate Change Conference in Bonn, Germany (COP23) [Online]. European Parliament. Available: http://www.europarl.europa.eu/sides/getDoc.do?pubRef=//EP//TEXT+CRE+20171003+ITEM-013+DOC+XML+V0//EN [Accessed 12.04.2018 2018].

- $\quad$ BALCZÓ, Z. 2017b. Eastern Partnership: November 2017 Summit (debate) [Online]. European Parliament. Available: http:/www.europarl.europa.eu/sides/getDoc.do?pubRef=//EP//TEXT+CRE+20171114+ITEM-014+DOC+XML+V0//EN [Accessed 29.03.2018 2018]. 
- $\quad$ BALCZÓ, Z. 2017c. EU defence plan and the future of Europe (topical debate)

[Online]. European Parliament. Available:

http://www.europarl.europa.eu/sides/getDoc.do?pubRef=-

//EP//TEXT+CRE+20170704+ITEM-012+DOC+XML+V0//EN [Accessed 3.04.2018 2018].

- BENOIT, B. 1997. Social-nationalism: an anatomy of French euroscepticism, Aldershot, Ashgate.

- $\quad$ BESWICK, E. 2017. Who is Béla Kovács - the Hungarian MEP charged with spying on the EU? [Online]. euronews. Available: http://www.euronews.com/2017/12/07/who-isbela-kovacs-the-hungarian-mep-charged-with-spying-for-the-kgb- [Accessed 23.03.2018 2018].

- $\quad$ BOSAK, K. 2016. Skoro przez ostatnie 10 lat mogliśmy funkcjonować bez CETA $i$ TTIP, to możemy kolejne 10 [Online]. Telewizja Republika. Available: http://telewizjarepublika.pl/bosak-skoro-przez-ostatnie-10-lat-moglismy-funkcjonowac-bezceta-i-ttip-to-mozemy-kolejne-10,39319.html [Accessed 23.04.2018 2018].

- $\quad$ BRACK, N. 2012. Euroscepticism at the Supranational Level: The Case of the 'Untidy Right' in the European Parliament*. JCMS: Journal of Common Market Studies, 51, 85-104.

- $\quad$ CHRUSZCZ, S. \& DZIAMBOR, A. 2014. Polityk KNP: "UE nie powinna sie mieszać w sprawy Ukrainy” [Online]. PolskieRadio.pl. Available: https://www.polskieradio.pl/9/301/Artykul/1120776,Polityk-KNP-UE-nie-powinna-siemieszac-w-sprawy-Ukrainy [Accessed 29.03.2018 2018].

- DIEZ, T. 1996. Postmoderne Und Europäische Integration. Die Dominanz Des Staatsmodells, Die Verantwortung Gegenüber Dem Anderen Und Die Konstruktion Eines Alternativen Horizonts. Zeitschrift Für Internationale Beziehungen, 3, 255-281.

- $\quad$ DIEZ, T. 1998. The Economist Community Reading of Europe: Its Discursive Nodal Points and Ambiguities Towards "Westphalia". COPRI Working Papers, 6.

- $\quad$ EIERMANN, M., MOUNK, Y. \& GULTCHIN, L. 2017. European Populism: Trends, Threats and Future Prospects. Tony Blair Institute for Global Change.

- $\quad$ FIALA, R. 2017. Rusko je pro nás důležitá země a je velmi správné, že prezident Zeman dává velkou váhu dobrým vztahům $k$ Rusku [Online]. SPD. Available: 
http://www.spd.cz/novinky/radim-fiala-rusko-je-pro-nas-dulezita-zeme-a-je-velmi-spravneze-prezident-zeman-dava-velkou-vahu-dobrym-vztahum-k-rusku [Accessed 29.03.2018 2018].

- $\quad$ FLOOD, C. \& SOBORSKI, R. 2018. Euroscepticism as ideology. In: LERUTH, B., STARTIN, N. \& USHERWOOD, S. (eds.) The Routledge Handbook of Euroscepticism. Abingdon: Routledge.

- $\quad$ FTV, P. 2014. Okamura v Partii: Sankce proti Rusku ohrozí př́liv ruských turisti̊ a pracovní místa [Online]. Available: https://domaci.ihned.cz/c1-61899990-tomio-okamurausvit-cizinci-odsun-deportace-rusko-sankce-priliv-turistu [Accessed 29.03.2018 2018].

- GERGELY, K. 2016. Nem kér a Jobbik a közös európai hadseregböl [Online]. Alfahir. Available: https://alfahir.hu/nem_ker_a_jobbik_a_kozos_europai_hadseregbol [Accessed 3.04.2018 2018].

- HRNČ́́Í, J. 2016. Smlouvy TTIP a TISA? Zotročení Evropanů nadosah [Online]. Available: https://www.parlamentnilisty.cz/politika/politici-volicum/Hrncir-SPD-SmlouvyTTIP-a-TISA-Zotroceni-Evropanu-nadosah-433746 [Accessed 2018].

- HUTKO, D. 2017. Danko: Zamýšl’am sa, či sankcie proti Rusku fungujú [Online]. Pravda. Available: https://spravy.pravda.sk/domace/clanok/448573-danko-zamyslam-sa-cisankcie-proti-rusku-funguju/ [Accessed 30.03.2018 2018].

- IWASZKIEWICZ, R. 2015. Negotiations for the Transatlantic Trade and Investment Partnership (TTIP) [Online]. European Parliament. Available: http://www.europarl.europa.eu/sides/getDoc.do?pubRef=//EP//TEXT+CRE+20150709+ITEM-013-01+DOC+XML+V0//EN [Accessed 22.04.2018 2018].

- $\quad$ IWASZKIEWICZ, R. 2017. EU Emissions Trading System (EU ETS): continuing current limitations of scope for aviation activities and preparing to implement a global market-based measure from 2021 [Online]. European Parliament. Available: http://www.europarl.europa.eu/sides/getDoc.do?pubRef=//EP//TEXT+CRE+20170913+ITEM-010-02+DOC+XML+V0//EN [Accessed 12.04.2018 2018]. 
- KORWIN-MIKKE, J. 2014. Situation in Ukraine and state of play of EU-Russia relations (debate) [Online]. European Parliament. Available: http://www.europarl.europa.eu/sides/getDoc.do?pubRef=//EP//TEXT+CRE+20140916+ITEM-004+DOC+XML+V0//EN [Accessed 27.03.2018 2018].

- $\quad$ KORWIN-MIKKE, J. 2015a. 8 pytań w sprawie TTIP. Kandydaci na prezydenta RP o umowie pomiędzy UE a USA [Online]. Gazeta Prawna. Available: http://biznes.gazetaprawna.pl/artykuly/869307,8-pytan-o-ttip-kandydaci-na-prezydenta-rpumowa-pomiedzy-ue-a-usa.html [Accessed 23.04.2018 2018].

- $\quad$ KORWIN-MIKKE, J. 2015b. Janusz Korwin-Mikke o armii europejskiej.

- $\quad$ KORWIN-MIKKE, J. 2016a. Implementation of the Common Security and Defence Policy [Online]. European Parliament. Available: http://www.europarl.europa.eu/sides/getDoc.do?pubRef=//EP//TEXT+CRE+20161122+ITEM-012+DOC+XML+V0//EN [Accessed 5.04.2018 2018]. - KORWIN-MIKKE, J. 2016b. Space capabilities for European security and defence [Online]. European Parliament. Available: http://www.europarl.europa.eu/sides/getDoc.do?pubRef=//EP//TEXT+CRE+20160608+ITEM-013-15+DOC+XML+V0//EN [Accessed 4.04.2018 2018].

- KORWIN-MIKKE, J. 2017b. Annual report on the implementation of the Common Security and Defence Policy - Annual report on the implementation of the Common Foreign and Security Policy - Permanent Structured Cooperation (PESCO) - opening a new chapter in European Security and Defence Policy [Online]. European Parliament. Available: http://www.europarl.europa.eu/sides/getDoc.do?pubRef=//EP//TEXT+CRE+20171212+ITEM-012+DOC+XML+V0//EN [Accessed 5.04.2018 2018]. - KORWIN-MIKKE, J. 2017c. EU defence plan and the future of Europe [Online]. European Parliament. Available: http://www.europarl.europa.eu/sides/getDoc.do?pubRef=//EP//TEXT+CRE+20170704+ITEM-012+DOC+XML+V0//EN [Accessed 4.04.2018 2018].

- $\quad$ KOVÁCS, B. 2015a. Role of local authorities in developing countries in development $\begin{array}{llll}\text { cooperation } & \text { [Online]. European Available: }\end{array}$ 
http://www.europarl.europa.eu/sides/getDoc.do?pubRef=//EP//TEXT+CRE+20151006+ITEM-008-12+DOC+XML+V0//EN [Accessed 17.04.2018 2018].

- $\quad$ KOVÁCS, B. 2015b. Security and defence capabilities in Europe [Online]. Available: http://www.europarl.europa.eu/sides/getDoc.do?pubRef=//EP//TEXT+CRE+20150521+ITEM-008-03+DOC+XML+V0//EN [Accessed 4.04.2018 2018].

- KOVÁCS, B. 2016a. 2015 Report on policy coherence for development [Online]. European Parliament. Available: http://www.europarl.europa.eu/sides/getDoc.do?pubRef=//EP//TEXT+CRE+20160607+ITEM-006-09+DOC+XML+V0//EN [Accessed 21.04.2018 2018].

- KOVÁCS, B. 2016b. European Defence Union [Online]. European Parliament. Available: $\quad$ http://www.europarl.europa.eu/sides/getDoc.do?pubRef=//EP//TEXT+CRE+20161122+ITEM-006-08+DOC+XML+V0//EN [Accessed 4.04.2018 2018].

- KOVÁCS, B. 2016c. The future of ACP-EU relations beyond 2020 [Online]. European Parliament. Available: http://www.europarl.europa.eu/sides/getDoc.do?pubRef=//EP//TEXT+CRE+20161004+ITEM-008-09+DOC+XML+V0//EN [Accessed 17.04.2018 2018].

- KREKÓ, P., GYŐRI, L. D., JEKATYERINA, JANDA, J. K., ONDŘEJ, MESEŽNIKOV, GRIGORIJ MESÍK, J., SZYLAR, M. \& SHEKHOVTSO, A. 2016. The Weaponization of Culture: Kremlin's traditional agenda and the export of values to Central Europe. Political Capital Institute.

- $\quad$ LERUTH, B., STARTIN, N. \& USHERWOOD, S. 2018. Defining Euroscepticism. From a broad concept to a field of study. In: LERUTH, B., STARTIN, N. \& USHERWOOD, S. (eds.) The Routledge Handbook of Euroscepticism. Abingdon: Routledge.

- LORD, C. 1998. The Untidy Right in the European Parliament. In: BELL, D. \& LORD, C. (eds.) Transnational Parties in the European Union. London: Routledge.

- MACH, P. 2014. Transatlantic Trade and Investment Partnership (TTIP [Online]. Euroepan Parliament. Available: http://www.europarl.europa.eu/sides/getDoc.do?pubRef=- 
//EP//TEXT+CRE+20140715+ITEM-009+DOC+XML+V0//EN [Accessed 23.04.2018 2018].

- $\quad$ MACH, P. 2015a. Implementation of the Common Security and Defence Policy (A80054/2015 - Arnaud Danjean) [Online]. European Parliament. Available: http://www.europarl.europa.eu/sides/getDoc.do?pubRef=-

//EP//TEXT+CRE+20150521+ITEM-008-01+DOC+XML+V0//EN [Accessed 3.04.2018 2018].

- MACH, P. 2015b. Negotiations for the Transatlantic Trade and Investment Partnership (TTIP) [Online]. European Parliament. Available: http://www.europarl.europa.eu/sides/getDoc.do?pubRef=//EP//TEXT+CRE+20150707+ITEM-004+DOC+XML+V0//EN [Accessed 22.04.2018 2018].

- MACH, P. 2016a. 2015 Report on policy coherence for development [Online]. European Parliament. Available: http://www.europarl.europa.eu/sides/getDoc.do?pubRef=//EP//TEXT+CRE+20160607+ITEM-006-09+DOC+XML+V0//EN [Accessed 18.04.2018 2018].

- $\quad$ MACH, P. 2016b. 2016 UN Climate change Conference in Marrakesh, Morocco (COP22) [Online]. Available: http://www.europarl.europa.eu/sides/getDoc.do?pubRef=//EP//TEXT+CRE+20161006+ITEM-006-03+DOC+XML+V0//EN [Accessed 12.04.2018 2018].

- $\quad$ MACH, P. 2016c. Conclusion on behalf of the EU of the Paris Agreement adopted under the UN Framework Convention on Climate Change [Online]. European Parliament. Available: $\quad$ http://www.europarl.europa.eu/sides/getDoc.do?pubRef=//EP//TEXT+CRE+20161004+ITEM-008-01+DOC+XML+V0//EN [Accessed 12.04.2018 2018].

- $\quad$ MACH, P. 2016d. Implementation of the Common Foreign and Security Policy (Article 36 TEU) [Online]. European Parliament. Available: http://www.europarl.europa.eu/sides/getDoc.do?pubRef=//EP//TEXT+CRE+20161214+ITEM-010-16+DOC+XML+V0//EN [Accessed 7.04.2018 2018]. 
- $\quad$ MACH, P. 2016e. Mutual defence clause (Article 42(7) TEU) [Online]. European Parliament. $\quad$ Available: $\quad$ http://www.europarl.europa.eu/sides/getDoc.do?pubRef=//EP//TEXT+CRE+20160121+ITEM-009-04+DOC+XML+V0//EN [Accessed 3.04.2018 2018].

- $\quad$ MACH, P. 2016f. Products originating in certain ACP states [Online]. European Parliament. Available: $\quad$ http://www.europarl.europa.eu/sides/getDoc.do?pubRef=//EP//TEXT+CRE+20160412+ITEM-006-01+DOC+XML+V0//EN [Accessed 18.03.2018 2018].

- $\quad$ MACH, P. 2016g. The future of ACP-EU relations beyond 2020 [Online]. European Parliament. Available: $\quad$ http://www.europarl.europa.eu/sides/getDoc.do?pubRef=//EP//TEXT+CRE+20161004+ITEM-008-09+DOC+XML+V0//EN [Accessed 18.04.2018 2018].

- MARUSIK, M. 2015. Towards a new international climate agreement in Paris [Online]. Available: $\quad$ http://www.europarl.europa.eu/sides/getDoc.do?pubRef=//EP//TEXT+CRE+20151014+ITEM-014+DOC+XML+V0//EN [Accessed 12.04.2018 2018].

- $\quad$ MARUSIK, M. 2016. 2016 UN Climate change Conference in Marrakesh, Morocco (COP22) [Online]. European Parliament. Available: http://www.europarl.europa.eu/sides/getDoc.do?pubRef=//EP//TEXT+CRE+20161006+ITEM-006-03+DOC+XML+V0//EN [Accessed 12.04.2018 2018].

- $\quad$ MARUSIK, M. 2017. Annual report on the implementation of the Common Security and Defence Policy - Annual report on the implementation of the Common Foreign and Security Policy - Permanent Structured Cooperation (PESCO) - opening a new chapter in European Security and Defence Policy (debate) [Online]. Available: http://www.europarl.europa.eu/sides/getDoc.do?pubRef=//EP//TEXT+CRE+20171212+ITEM-012+DOC+XML+V0//EN [Accessed 4.04.2018 2018].

- $\quad$ MAZUREK, M. 2015. O pokrytectve a klamstvách Roberta Fica [Online]. L'SNS. Available: http://www.naseslovensko.net/nase-nazory/o-pokrytectve-a-klamstvach-robertafica/ [Accessed 29.03.2018 2018]. 
Issue no. $26 / 2018$

- OKAMURA, T. 2014. Změna klimatu [Online]. Available: http://www.tomio.cz/aktuality/zmena-klimatu/ [Accessed 12.04.2018 2018].

- $\quad$ OKAMURA, T. 2016. Chystá se ekonomické zotročení evropských států.

- $\quad$ OKAMURA, T. 2017. Svoboda a prímá demokracie Tomio Okamura - SPD [Online]. Available:

https://www.facebook.com/hnutispd/posts/1700787779952060?comment_id=170083140328 1031\&comment tracking=\%7B\%22tn\%22\%3A\%22R0\%22\%7D $\quad$ [Accessed 4.04.2018 2018].

- $\quad$ RN 2016a. Ruch Narodowy i Młodzież Wszechpolska przeciwko CETA i TTIP zapowiedź manifestacji.

- RN. 2016b. Tożsamość - Suwerenność - Wolność. Deklaracja ideowa Ruchu Narodowego [Online]. Ruch Narodowy. Available: http://ruchnarodowy.net/program/ [Accessed 13.04.2018 2018].

- SPD. 2017a. Politický program SPD [Online]. SPD. Available: http://www.spd.cz/program [Accessed 3.04.2018 2018].

- $\quad$ SPD 2017b. SPD zahranićní politika. SPD.

- SPD. 2017c. Svoboda a prímá demokracie Tomio Okamura - SPD [Online]. Available:

https://www.facebook.com/hnutispd/posts/1700787779952060?comment_id=170083140328 1031\&comment_tracking=\%7B\%22tn\%22\%3A\%22R0\%22\%7D [Accessed 4.04.2018 2018].

- SPD. 2018. Váženi přátelé, toto jsou aktuální informace a stanoviska hnutí SPD. Prosím sdílejte a posílejte dál! [Online]. SPD. Available: http://www.spd.cz/novinky/politicke-usneseni-spd-2983 [Accessed 27.03.2018 2018].

- $\quad$ SPIERING, M. 2004. British Euroscepticism. In: HARMSEN, R. \& SPIERING, M. (eds.) Euroscepticism: Party Politics, National Identity and European Integration. Amsterdam: Rodopi.

- $\quad$ STE. 2016a. Saskárka Kiššová posiela Kollárovi, Blahovi a Uhríkovi jasný odkaz [Online]. Available: https://www.parlamentnelisty.sk/arena/monitor/Saskarka-Kissovaposiela-Kollarovi-Blahovi-a-Uhrikovi-jasny-odkaz-270926 [Accessed 23.04.2018 2018]. 
- $\quad$ STE. 2016b. Zrada na národe! Osvojila si to na americkej ambasáde. Oblbujú nás. Antisystémista Kollár, marxista Blaha a kotlebovec Uhrík si svorne podali liberálku [Online]. Available: https://www.parlamentnelisty.sk/arena/monitor/Zrada-na-narode-Osvojila-si-tona-americkej-ambasade-Oblbuju-nas-Antisystemista-Kollar-marxista-Blaha-a-kotlebovecUhrik-si-svorne-podali-liberalku-270466 [Accessed 23.04.2018 2018].

- SZCZERBIAK, A. \& TAGGART, P. 2018. Contemporary Research on Euroscepticism. The state of the art. In: LERUTH, B., STARTIN, N. \& USHERWOOD, S. (eds.) The Routledge Handbook of Euroscepticism. Abingdon: Routledge.

- $\quad$ TAGGART, P. 2003. A Touchstone of Dissent: Euroscepticism in Contemporary Western European Party Systems. European Journal of Political Research, 33, 363-388.

- $\quad$ TASR. 2017. S Ruskom sme predurčení na spoluprácu, vyhlásil Danko. Chce prekonat' súčasné obdobie [Online]. finweb. Available: https://finweb.hnonline.sk/ekonomika/983832-s-ruskom-sme-predurceni-na-spolupracuvyhlasil-danko-chce-prekonat-sucasne-obdobie [Accessed 30.03.2018 2018].

- TERESZKIEWICZ, F. 2016a. Konstruktywizm jako perspektywa badawcza w wyjaśnianiu zachowań eurosceptyków w Parlamencie Europejskim w obszarze działań zewnętrznych UE. Przegląd Europejski, 3, 10-28.

- $\quad$ TERESZKIEWICZ, F. 2016b. Partie antyunijne wobec głównych kierunków działań zewnętrznych Unii Europejskiej. In: MUSIAŁ-KARG, M. (ed.) Bezpieczeństwo Europy $i$ Unii Europejskiej w czasach kryzysu. Poznań: Wydawnictwo Naukowe WNPiD UAM.

- $\quad$ TESAŘOVÁ, M. 2017. Krym a Donbas jsou ruské, tvrdí Tomio Okamura z SPD [Online]. ESJnews.com. Available: https://www.esjnews.com/cs/tomio-okamura [Accessed 27.03.2018 2018].

- VASILOPOULOU, S. 2011. European Integration and the Radical Right: Three Patterns of Opposition. Government and Opposition, 46, 223-244.

- VASILOPOULOU, S. 2018. Theory, concepts and research designed in the study of Euroscepticism. In: LERUTH, B., STARTIN, N. \& USHERWOOD, S. (eds.) The Routledge Handbook of Euroscepticism. Abingdon: Routledge.

- VEF. 2017. SNS: Rozvojová pomoc SR: Pomôž blížnemu, pomôžeš aj sebe [Online]. ParlamentnéListy.sk. Available: $\quad$ https://www.parlamentnelisty.sk/politika/politici- 
volicom/SNS-Rozvojova-pomoc-SR-Pomoz-bliznemu-pomozes-aj-sebe-293393 [Accessed 18.04.2018 2018].

- WINNICKI, R. 2016. Zapis przebiegu posiedzenia komisji. In: 10/, K. D. S. E. I. S. P. N. (ed.). Sejm.

- $\quad$ WINNICKI, R. 2017. Eurokorpus jeśli miałby być przydatny to do obrony wspólnych granic UE [Online]. Ruch Narodowy. Available: http://ruchnarodowy.net/robert-winnickieurokorpus-jesli-mialby-byc-przydatny-obrony-wspolnych-granic-ue/ [Accessed 7.04.2018 2018].

- $\quad$ ZUBA, K. 2006. Polski eurosceptycyzm i eurorealizm, Opole, Wydawnictwo Uniwersytetu Opolskiego.

- $\quad$ ŠVEC, M. 2017. SPD chce zrušit sankce, komunisté i ANO souhlasí, píší v Rusku. Jen osobní názor, couvají politici [Online]. aktualne.cz. Available: https://zpravy.aktualne.cz/zahranici/spd-chce-zrusit-sankce-komuniste-i-ano-to-podpori-pisiv-rus/r e33658f8bd5711e7a49e0025900fea04/?redirected=1524504204

[Accessed 29.03.2018 2018]. 